\title{
RELIGIOUS EDUCATION AND TOLERANCE: LEARNING PROCESS IN HIGH SCHOOL OF MINORITY MUSLIM INDONESIA
}

\author{
Ismail Suardi Wekke, Sabil Mokodenseho, Firdaus \\ Sekolah Tinggi Agama Islam Negeri (STAIN) Sorong, West Papua, Indonesia \\ Institut Agama Islam Negeri Manado (IAIN), North Sulawesi, Indonesia \\ Sekolah Tinggi Keguruan dan ilmu Pendidikan (STKIP) PGRI Sumatera Barat, \\ Indonesia.
}

\begin{abstract}
The plural religious phenomenon has shown the goodness perspective and the diversity universally and inclusively. The emergence of this thought, obviously, will replace products of religious doctrines for the people who believe that the truest religion is a specific religion embraced by specific people while the others are false. The research was conducted in Manado, North Sulawesi of Indonesia where minority Muslim exists. In the context of multireligious society, Islamic education taught in schools is required to embed values of religious tolerance. This paper discusses the embedding process of the values of religious tolerance within Islamic lesson in senior high school of Manado. The learning processes allow students chances to practice their religious lessons appropriately with their respective religions. In addition, they have the opportunity in creating learning atmosphere with religious diversity, building mutual trust among them, keeping mutual understanding each other, upholding mutual love, going deep into materials about tolerance and guiding and giving motivation to the students in doing activities relating to tolerance as by not differentiate Muslim and non-Muslim students.
\end{abstract}

Keywords: Muslim, diversity, tolerance, atmosphere, learning process

\section{INTRODUCTION}

In Islam, mankind has full guarantee of the freedom of religion. Islam assesses that requirement to create a harmony is recognition of the components that are naturally different. As Islam, other great religions are also teaching moral norms to manage social life. Hindu teaches moral norms for daily life. Christian accentuates spirituality aspect in embedding moral values. Furthermore, Islam which teaches morality towards self, others, flora and fauna and towards Allah (Burdbar Khan \& Nisar Sheikh, 2012). Such diversity, in one hand, is the nation's wealth that is invaluable and potential to support the interests of development and prosperity of the nation. But in the other hand, it also hides number of potentials of social conflicts which can threat the unity of the state (disintegration) (Sebastian, 2015).

The diversity is often exploited and misinterpreted by particular person or groups to fuel tensions between ethnics, religions, races and groups (Bangwayo-Skeete \& Zikhali, 2011). For instance, there were conflicts between Ambon and Poso (religious conflict), between Sanggau Ledo, Sambas and Sampit (conflict between Dayak, Malay, and Madura) and the tragedy of May, 1998 as "political conflict which had led to anti-Chinese sentiment". The same picture was in India, Australia, and other countries (S. Croucher, 2011; S. M. Croucher et al., 2011; Sav, Harris, \& Sebar, 2013).

Therefore, education is responsible to embed positive attitude towards the multicultural condition of our nation. Inviting others to embrace one faith is not prohibited but should be performed in a dignified manner 
and without violence. Moreover, education should give the students, as soon as possible, awareness of the importance of appreciation to the diversity of humans' religions. Outputs of education which have given the concept of awareness will not be too eager to change other's faith by coercion or violence (Wainscott, 2015). In relation to the education process in schools, it is worthy to know what the typical characteristics of Islamic education are. One of such characteristics is not only bringing the students to master various Islamic teaching, but also, the most important thing, how lead them to practice these teachings in their daily lives. Nor and Malim (Roslan Mohd Nor \& Malim, 2014) figure out that the position of Islamic education in various levels in national education was to realize students who are faithful, devoted and noble.

Islamic educational materials are developed from three basic frameworks of Islamic teachings are the concept of iman, syariah from the concept of Islam and akhlak from the concept of ihsan (Izfanna \& Hisyam, 2012). Based on the three basic concepts, various Islamic reviews are developed, including reviews related to sciences, technology, arts and cultures (McGregor, 2009). This article would identify how is the religious relationship in Islamic education in Public Senior High School 9 of Manado.

\section{RESEARCH METHOD}

This research used qualitative approach. Data appointed were not in numeric form but taken from interview texts and field notes, so that the objectives of this qualitative research was to describe empirical reality behind the phenomenon in deep, detailed and completed manners (Cohen, Manion, \& Morrison, 2007; Ingleby, 2012; Mathiassen, 2002; Rusly, Corner, \& Sun, 2012). In addition, this use of qualitative approach was done by comparing empirical reality by applied theory using descriptive method. The qualitative research method used was naturalistic research which was done in natural condition (Cohen et al., 2007).

This research was done for approximately two months, started from July 2016 until August 2016 in Public Senior High School 9 of Manado, the District of Malalayang, Manado City. The extension for three months in conducting triangulation (Pashiardis, 2015; Whipple \& Russell, 2007). It was done based on a consideration to that the school had typical characteristics which were in accordance with problems observed. Data collection was performed using two methods; they are in-depth-interview and nonparticipant-observation. Interview were conducted using same questions to 18 respondents consisting of one teacher of Islamic religious lesson, one teacher of Christian religious lesson, one teacher of Catholic religious lesson, five Islamic students, five Christian students and five Catholic students.

\section{FINDINGS AND DISCUSSION}

The embedding process of the values of religious tolerance within Islamic lesson in Public Senior High School 9 of Manado was done by giving the students chances to follow religious lessons appropriately with their respective religions, creating learning atmosphere with religious diversity, building mutual trust among them, keeping mutual understanding each other, upholding mutual love, going deep into materials about tolerance and guiding and giving motivation to the students in doing activities relating to tolerance as by not discriminating Muslim and non-Muslim students. Islamic education which was a sub-system of national education system was one of most effective media to generate generation which has an insight which is able to take the diversity as a part which should be appreciated constructively (Gebert, Boerner, \& Chatterjee, 2011; Mir, 2013; Sengupta \& Sarkar, 2012).

Therefore, which this learning atmosphere, the students were expected to be able to develop tasamuh attitude both in the school and in the society. In term of method, the method used by the teacher in the learning process should not contradictive. Learning strategy used by the teachers was cooperative teaching learning in social intercourse which had various properties and be able to create pleasant atmosphere. Cooperative learning process would encourage the students to study about positive sides form their friends (Economides, 2008; Strang, 2015). In turn, they would be conditioned within the learning process where a student is studying together with others in the atmosphere containing mutual respect, tolerant and understanding each other (Abdelrahman, Mohammed, Farrag, \& Hassan, 2015; Jackling, Cooper, Leung, \& Dellaportas, 2007; van der Noll \& Saroglou, 2014). 
Moreover, the students were expected to have different perspective compared to the former perspective. They should have democratic and pluralist perspective and interpretation, as well as be able to respect for other's culture. Along with advances in technology, learning media had great influence on the development of education in schools, so that the learning tools or media should be adjusted to such advances technology. The use of media of technology made the learning process to be more effective and efficient. Not only that, the development of education in schools was increasingly changing and encouraging various efforts to change. Learning process needed facilitations which can be used as intermediary media to enhance the effectiveness and efficiency to achieve the goals of education. At least, the media should be effective and efficient in terms of their forms, environmental components, physical equipment and communication. As well as Islamic education, it also needed learning facilities to improve students' active participation in the learning and teaching processes. Islamic education's learning media were things that could be taken as facilities and infrastructure used to help to achieve the goals of Islamic education (Barton \& Andre, 2014; Kraft \& Basinger, 2010; Sudarat Tuntivivat, 2016).

In fact, for the learning media used to embed values of religious tolerance in religious lessons in Public Senior High School 9 of Manado were curriculum, supporting textbooks, print media, electronic media (laptop and projector), audio-visual media and internet network. With these media, it will be easier for the teacher to explain to the students about tolerance in religious life. In addition to that, in the process of Islamic education using those media, it was expected that the students are not just copying or imitating what they get but also are attempting actively to do everything based to their faith (Darmanin, 2013; Thobani, 2007; Tibi, 2007).

Therefore, in the process of learning Islamic education, the presence of learning media was very important and a must. The absence of learning media was significantly influencing learning and teaching processes since they can help to solve the unclearness of the materials so that the materials can be delivered clearly and acceptable. The difference of religions and faiths in Public Senior High School 9 of Manado did not influence the continuity of all religious lessons. The students of the school see such difference as thing should be kept well to create harmonic relationships. This was inseparable from the teachers' roles in embedding values of religious tolerance in students' minds through learning materials (Wekke, 2015).

\section{CONCLUSION}

To foster this attitude, education, mainly Islamic education, was the most appropriate way to sow the seeds of tolerance, life harmony and sincere appreciation to the reality of the diversity of cultural-religious aspect of the community since Islamic education was a sub-system of national education which was the most effective medium to generate a generation having an insight that is able to make the diversity to be a part which should be appreciated constructively. At least, Islamic education is able to give consciousness to the people that conflict is not a good thing to civilize. It is also able to offer educating solutions such as by designing materials, methods and curriculums that are giving to the people rooms of consciousness about the importance of tolerant attitude, respecting for the diversity of tribes, religion, races, ethnics and cultures of multicultural Indonesian people.

\section{REFERENCE}

Abdelrahman, D., Mohammed, F., Farrag, D. A., \& Hassan, M. (2015). The influence of religiosity on Egyptian Muslim youths ' attitude towards fashion.

Bangwayo-Skeete, P. F., \& Zikhali, P. (2011). Social tolerance for human diversity in Sub-Saharan Africa. International Journal of Social Economics, 38(6), 516-536.

Barton, G., \& Andre, V. (2014). Islam and Muslim-Buddhist and Muslim-Christian Relations in Southeast Asia. Islam and Christian-Muslim Relations, 25(3), 281-285.

Burdbar Khan, M., \& Nisar Sheikh, N. (2012). Human resource development, motivation and Islam. Journal of Management Development, 31(10), 1021-1034. 
Cohen, L., Manion, L., \& Morrison, K. (2007). Research Methods in Education. Education (Vol. 55).

Croucher, S. (2011). Muslim and Christian conflict styles in Western Europe. International Journal of Conflict Management, 22(1), 60-74.

Croucher, S. M., Holody, K. J., Hicks, M. V, Oommen, D., Demaris, A., \& Croucher, S. M. (2011). An examination of conflict style preferences in India.

Darmanin, M. (2013). The "smallness" of minimalist tolerance. Education, 4(1), 31-62.

Economides, A. A. (2008). Culture-aware collaborative learning. Multicultural Education \& Technology Journal, 2(4), 243-267.

Gebert, D., Boerner, S., \& Chatterjee, D. (2011). Do religious differences matter? An analysis in India. Team Performance Management, 17(3/4), 224-240.

Ingleby, E. (2012). Research methods in education. Professional Development in Education. https://doi.org/10.1080/19415257.2011.643130

Izfanna, D., \& Hisyam, N. A. (2012). A comprehensive approach in developing akhlaq. Multicultural Education \& Technology Journal, 6(2), 77-86.

Jackling, B., Cooper, B. J., Leung, P., \& Dellaportas, S. (2007). Professional accounting bodies' perceptions of ethical issues, causes of ethical failure and ethics education. Managerial Auditing Journal, 22(9), 928-944.

Kraft, J. (ed), \& Basinger, D. (ed). (2010). Religious Tolerance through Humility: Thinking with Philip Quinn. Faith and Philosophy: Journal of the Society of Christian Philosophers, 27(2), 226-228.

Mathiassen, L. (2002). Collaborative practice research. Information Technology \& People, 15(4), 321345 .

McGregor, E. K. (2009). Confronting the Past in Contemporary Indonesia. Critical Asian Studies, 41(2), 195-224.

Mir, R. a. (2013). Religion as a coping mechanism for global labor. Equality, Diversity and Inclusion: An International Journal, 32(3), 325-337.

Pashiardis, georgia K. P. (2015). time management profiles of cypriot school prinsipals: a mixed-methods approach. International Journa of Educational Management, 29(4), 492-518.

Roslan Mohd Nor, M., \& Malim, M. (2014). Revisiting Islamic education: the case of Indonesia. Journal for Multicultural Education, 8(4), 261-276.

Rusly, F. H., Corner, J. L., \& Sun, P. (2012). Positioning change readiness in knowledge management research. Journal of Knowledge Management, 16(2), 329-355.

Sav, A., Harris, N., \& Sebar, B. (2013). Work-life conflict and facilitation among Australian Muslim men. Equality, Diversity and Inclusion: An International Journal, 32(7), 671-687.

Sebastian, C. L. (2015). Social cognition in adolescence: Social rejection and theory of mind. Psicología Educativa, 21(2), 125-131.

Sengupta, J., \& Sarkar, D. (2012). Caste and religious diversity on formation of social capital. Equality, Diversity and Inclusion: An International Journal, 31(2), 158-175.

Strang, K. (2015). Effectiveness of instructor-led collaborative learning in the classroom. Journal of Applied Research in Education, 7(2), 1-203.

Sudarat Tuntivivat. (2016). The inter-relationship between violence and education amidst armed conflict in southern Thailand. Journal of Aggression, Conflict and Peace Research Iss, 8(4). 
Thobani, S. (2007). The Dilemma of Islam as School Knowledge in Muslim Education. Asia Pacific Journal of Education, 27(April), 11-25.

Tibi, B. (2007). The Totalitarianism of Jihadist Islamism and its Challenge to Europe and to Islam. Totalitarian Movements and Political Religions, 8(1), 35-54.

Van der Noll, J., \& Saroglou, V. (2014). Anti-Islam or Anti-religion? Understanding Objection against Islamic Education. Journal of Ethnic and Migration Studies, 9451(September), 1-20.

Wainscott, A. M. (2015). Defending Islamic education: War on Terror discourse and religious education in twenty-first-century Morocco. The Journal of North African Studies, 20(4), 635-653.

Wekke, I. S. (2015). Arabic Teaching and Learning : A Model From Indonesian Muslim Minority. Procedia - Social and Behavioral Sciences, 191, 286-290.

Whipple, J. M., \& Russell, D. (2007). Building supply chain collaboration: a typology of collaborative approaches. The International Journal of Logistics Management, 18(2), 174-196. 